\author{
Renata Rettinger \\ Uniwersytet Pedagogiczny \\ im. Komisji Edukacji Narodowej \\ w Krakowie
}

\title{
Turystyka jako czynnik aktywizacji gospodarki Chorwacji
}

Chorwacja od wielu lat należy do obszarów o dobrze rozwiniętej funkcji turystycznej i dodatnim bilansie w zagranicznych obrotach turystycznych. Turystyka w tym kraju jest źródłem takich korzyści, jak wzrost produktu krajowego brutto, wpływów dewizowych, przychodów publicznych, zatrudnienia i dochodów ludności oraz rozwoju regionalnego. Ekonomiczna funkcja turystyki jest widoczna w wielu sferach gospodarowania, a w szczególności powoduje ona zróżnicowanie w przestrzennej strukturze podziału dochodu narodowego wytwarzanego przez turystykę. W wyniku tego następuje aktywizacja społeczno-gospodarcza regionów turystycznych. Istotnym miernikiem znaczenia turystyki zagranicznej w gospodarce narodowej jest stosunek wpływów z tej działalności do dochodu narodowego. W badaniach międzynarodowych przyjęto zasadę, że jeżeli ten stosunek jest większy od jedności, wtedy wpływy z turystyki zagranicznej są odczuwalne dla gospodarki narodowej (Gaworecki 2007). W przypadku Chorwacji turystyka stanowi znaczne źródło finansowania rozwoju społeczno-gospodarczego. Do najważniejszych uwarunkowań rozwoju turystyki w tym kraju na pewno należą warunki środowiska przyrodniczego, materialne i niematerialne dziedzictwo kulturowe oraz poziom rozwoju gospodarki turystycznej. Ta ostatnia rozumiana jest jako zdolność usługowa podmiotów gospodarczych zajmujących się zaspokajaniem popytu turystycznego. Dotyczy to przede wszystkim obiektów noclegowych, gastronomicznych, handlowych oraz bazy towarzyszącej i paraturystycznej. W niniejszym artykule zostanie przedstawiona analiza uwarunkowań rozwoju turystyki w Chorwacji oraz stan i przestrzenne zróżnicowanie zagospodarowania turystycznego oraz ruchu turystycznego. W opracowaniu zostaną uwzględnione także ekonomiczne uwarunkowania oraz skutki rozwoju turystyki tego kraju.

\section{Przyrodnicze i kulturowe uwarunkowania rozwoju turystyki}

Obszar Chorwacji można podzielić na dwie części: kontynentalną oraz wybrzeże. Są one od siebie oddzielone pasmem Gór Dynarskich, schodzących bezpośrednio do morza, co stanowi dodatkowy walor turystyczny tego obszaru. Chorwacja jest krajem nizinno-górzystym, 53\% obszaru leży na wysokości poniżej 200 m n.p.m. Obszary nizinne w północnej i wschodniej części kraju stanowią skraj Niziny Panońskiej. Środkową część Chorwacji zajmuje dolina rzeki Sawy wraz z jej dopływami. Na zachodzie i południu kraju rozciagają się Góry Dynarskie w postaci licznych, najczęściej równoległych do siebie pasm górskich. Zbudowane są one głównie z wapieni i dolomitów. Obszar ten nazywany jest Krasem Dynarskim (Gorski Kotar, Velika Kapela, Mala Kapela, Velebit), gdyż występują tu liczne krasowe formy terenu. Śródziemnomorski klimat decyduje o długości sezonu turystycznego (trwa on od maja do października), jak również o temperaturze wody w Adriatyku $\left(22-25^{\circ} \mathrm{C}\right)$. Występuje tu 


\section{Podsumowanie}

Chorwacja posiada szczególne walory zarówno przyrodnicze, jak i kulturowe dla rozwoju turystyki. Jednym z najważniejszych regionów turystycznych tego kraju jest obszar wybrzeża, w związku z tym zauważa się bardzo duże przestrzenne dysproporcje w zagospodarowaniu turystycznym, co bezpośrednio warunkuje wielkość i przestrzenne zróżnicowanie ruchu turystycznego. Negatywnym zjawiskiem obserwowanym w czasowym rozkładzie ruchu turystycznego jest jego sezonowość, która powoduje szeroko rozumiane negatywne konsekwencje ekonomiczne i społeczne. Chorwacja ze względu na swoje uwarunkowania jest krajem z bardzo dobrze rozwiniętą turystyka wypocznkową i poznawczą. W związku z tym podejmowane są liczne działania zmierzające do dalszej aktywizacji w zakresie wzbogacania oferty turystycznej regionów nadmorskich, takie jak tworzenie marin i centrów nurkowych

Gwałtowny rozwój infrastruktury turystycznej oraz ruchu turystycznego na stosunkowo niewielkim obszarze chorwackiego wybrzeża może w bardzo krótkim czasie doprowadzić do znacznego naruszenia stanu srodowiska przyrodniczego Chorwacji. Obecnie coraz częściej zauważa się problemy tych obszarów z dostępem do wody pitnej, z odprowadzaniem ścieków komunalnych czy też z wywozem śmieci z ośrodków turystycznych. Koniecznym jest już teraz wprowadzenie zasad polityki zrównoważonego rozwoju regionów turystycznyc. Z bardzo dużym uproszczeniem można przyjąć, że zrównoważony rozwój jest takim pożądanym przypadkiem rozwoju, w którym cele ekonomiczne, ekologiczne i społeczne są równoważne i zintegrowane, a tempo wzrostu gospodarczego nie jest większe od tempa reprodukcji zasobów przyrodniczych (Jędrzejczyk 1999).

Chorwacja, która w ciagu ostatnich 20 lat przeżywała kilka ciężkich kryzysów, łącznie z konfliktem zbrojnym, jest na etapie poszukiwania swojej pozycji w europejskim systemie społeczno-ekonomicznym. Na pewno jest to jeden z najważniejszych europejskich regionów turystycznych, cieszących się bardzo dużą popularnością wśród mieszkańców różnych części Europy. Z tego też faktu wynika ekonomiczna funkcja turystyki w tym kraju. Mieszkańcy Chorwacji, którzy muszą przełamać kryzys ekonomiczny, upatrują w turystyce jedno z głównych źródeł swojego utrzymania, co powoduje proces gwałtownej urbanizacji turystycznej chorwackich wybrzeży. Zjawisko to ma swoje pozytywne, jak i negatywne skutki. Nie należy zapominać, że dochodowość turystyki jako siła ekonomiczna likwiduje bariery i ograniczenia, nie zważając na konieczność pozostawienia przyszłym pokoleniom możliwości współżycia z nizmienioną naturą (Butler 2005). 
charakterystyczna przewaga opadów zimowych oraz letnie susze, które mogą trwać nawet cztery miesiące. Najlepsze przyrodnicze warunki dla rozwoju turystyki ma dalmatyńskie wybrzeże Adriatyku. Cechą charakterystyczną tego obszaru jest bardzo dobrze rozwinięta linia brzegowa (2092 km), z licznymi wyspami (1000 wysp). Szczególnym walorem krajobrazowym są liczne zatoki morskie, głęboko wciskające się w ląd o bardzo dużych deniwelacjach terenu.

Chorwacja należy do krajów o szczególnych walorach kulturowych, pochodzących zarówno z czasów starożytnych (greckie, rzymskie), wczesnośredniowiecznych oraz późniejszych (renesans). Pięć najważniejszych zabytkowych obiektów Chorwacji, które znajdują się na $\mathrm{Li}$ ście światowego dziedzictwa kulturalnego i przyrodniczego UNESCO to: Dubrownik, Trogir, zespół zabytkowy Splitu z Pałacem Dioklecjana, Katedra Św. Jakuba w Szybeniku, Bazylika Eufrazjusza w Poreću. Ponadto pod ochroną znajduje się niemal 340 zespołów zabytkowych, a także liczne pojedyncze obiekty.

Jak już wspomniano, jednym z ważniejszych regionów turystycznych Chorwacji jest wybrzeże adriatyckie, które możemy podzielić na trzy zasadnicze części. Najbardziej na północ wysuniętą częścią jest Wybrzeże Istriańsko-Kwarnerskie, w skład którego wchodzi Półwysep Istria, Zatoka Rijecka oraz Kanał Velebicki. Region ten swym zasięiem obejmuje także wyspy Krk, Cres, Losinj i Rab. Z punktu widzenia podziału administracyjnego są to następujące żupanie: istriańska, primorsko-goranska i licko-senjska (ryc. 1). Główne ośrodki turystyczne to: Opatija, Pula, Rovnij i Rijeka. Region ten charakteryzuje się wysokimi walorami przyrodniczymi oraz kulturowymi, które zadecydowały o długoletnich tradycjach rozwoju turystyki w tym regionie. Obszar ten obfituje w śródziemnomorskie krajobrazy, piaszczyste plaże, malownicze wioski i starożytne miasta, których rozkwit przypadał na okres imperium rzymskiego. Do dnia dzisiejszego zachowały się ruiny amfiteatrów, świątyń i pałaców. Ważnym elementem jest także bardzo dobra dostępność komunikacyjna, która warunkuje turystykę zagraniczną z takich krajów jak: Włochy, Austria, Czechy, Niemcy i Słowenia. Drugą częścią jest pas wybrzeża ciągnący się wzdłuż największego masywu górskiego Chorwacji - Velebitu. Najważniejsze ośrodki turystyczne regionu to Zadar i Sibenik oraz wyspy Pag, Dugi Otok, Ugljan i Pasman. Tu znajduje się jeden z bardziej znanych parków narodowych - Paklenica. Trzecia, ostatnia, część wybrzeża adriatyckiego to region splitsko-dalmatyński, w skład którego wchodzą dwie żupanie: splitsko-dalmatyńska i dubrownicko-neretwańska. Najważniejsze ośrodki turystyczne regionu to Split, Trogir, Klis i Salona. Wybrzeże tego regionu jest podzielone na mniejsze części, tzw. riwiery: Kastielanska, Omiska oraz Makarska, gdzie przede wszystkim koncentruje się ruch turystyczny - wypoczynkowy. Wypoczynek koncentruje się także na wyspach Bol i Supetar, w Postirze na wyspie Brac i w miejscowościach Stari Grad, Jelsa, Hvar na wyspie Hvar. W miejscowości Bol znajduje się markowy produkt turystyki chorwackiej - jedna z najładniejszych plaż, tzw. ,złoty róg” (Wiluś, Włodarczyk 1996). Chorwacja posiada liczne muzea i galerie, a także jest organizatorem festiwali muzycznych, filmowych i folklorystycznych.

\section{Infrastruktura turystyczna jako podstawa rozwoju funkcji turystycznej regionów}

Szczególne walory przyrodnicze i pozaprzyrodnicze Chorwacji stanowią podstawę rozwoju turystyki, ale należy pamiętać o uzupełniającej funkcji infrastruktury turystycznej, która zaspokaja popyt na różnego typu usługi. Stan i przestrzenne zróżnicowanie zagospodarowania turystycznego ma istotny wpływ na ruch turystyczny, co bezpośrednio przekłada się na rozwój funkcji turystycznej regionów Chorwacji. Wśród elementów zagospodarowania turystycznego szczególną rolę odgrywa baza noclegowa, jej stan i struktura. Chorwacja dysponuje dość bogatą turystyczną bazą noclegową, która łącznie obejmuje około 950 tys. miejsc noclegowych. 
Składają się nań miejsca w hotelach (12\%), ośrodkach wypoczynkowych $(6 \%)$, kempingach $(23 \%)$ oraz kwaterach prywatnych $(44 \%)$. Ten ostatni rodzaj obiektów noclegowych jest bardzo charakterystyczny dla Chorwacji i wiąże się z powszechnym zjawiskiem drugich domów. Kolejną cecha charakterystyczną chorwackiej bazy noclegowej jest stosunkowo niski udział hoteli o najwyższym standardzie 5 i 4 gwiazdek, które dysponują zaledwie 14\% udziałem w potencjale hotelowych miejsc noclegowych.

Ryc. 1. Parki narodowe oraz obiekty UNESCO na tle podziału administracyjnego Chorwacji

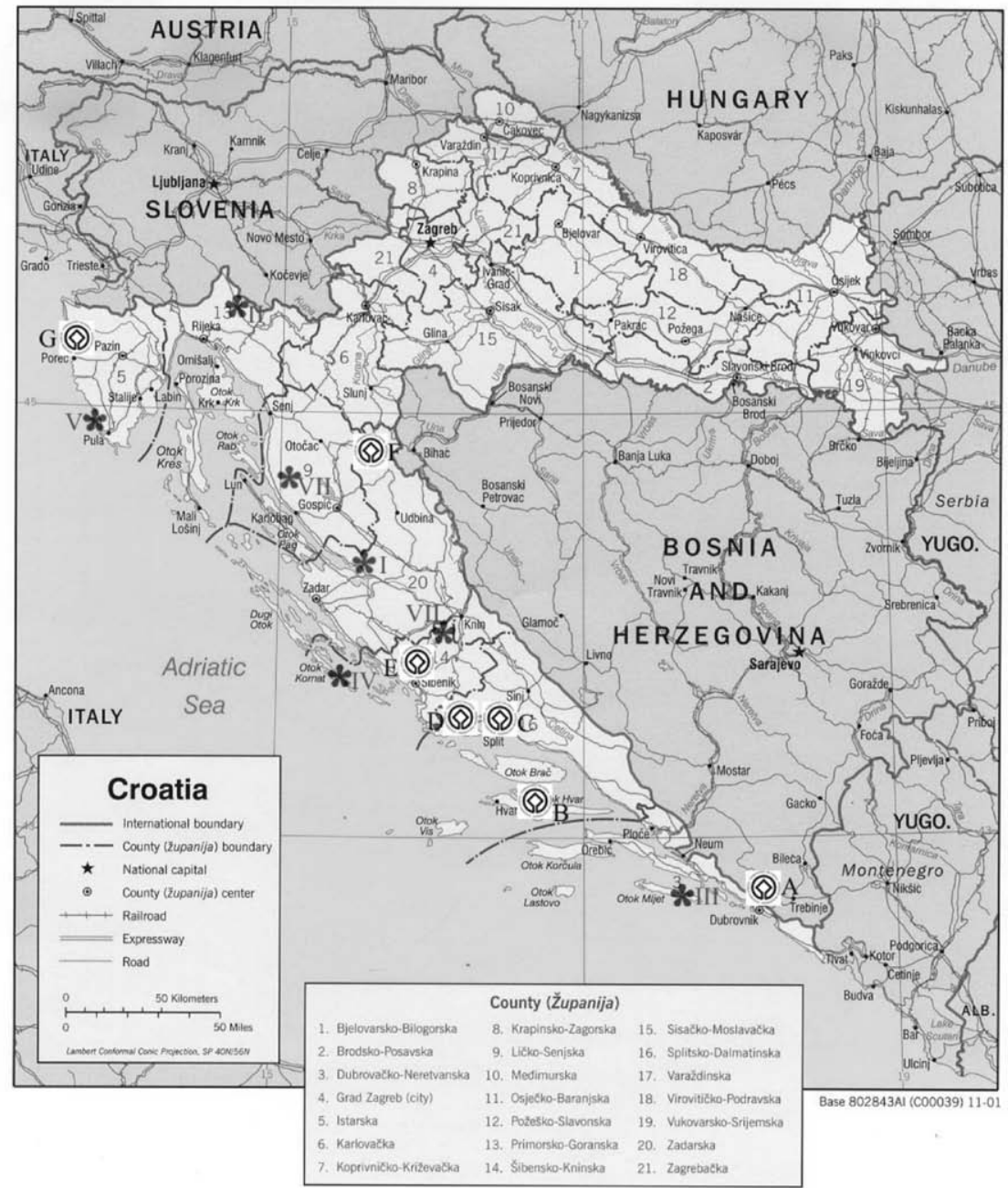

Obiekty z listy UNESCO: (8)

A Stare Miasto w Dubrovniku

B Nizina Stari Grad

C Kompleks pałacowy Dioklecjana w Splicie

D Centrum historyczne Trogiru

E Katedra św. Jakuba w Szybeniku

F Park Narodowy Jezior Plitwickich

G Bazylika Eufrazjana w Poreczu

Źródło: opracowanie własne.
Parki Narodowe: 2

F Jezior Plitwickich

I Paklenica

II Risnajk

III Mljet

IV Kornati

V Brijuni

VI Krka

VII Sjeverni Velebit 
Cechą charakterystyczną przestrzennego zróżnicowania zagospodarowania turystycznego jest jego duża koncentracja na niewielkim obszarze, są to głównie tereny nadmorskie. Znajduje się tu 94\% wszystkich miejsc noclegowych, którymi dysponuje Chorwacja (tab. 1). Rozmieszczenie infrastruktury turystycznej w strefie nadmorskiej ma wyraźny charakter liniowy i koncentruje się w najbliższej odległości od morza. Największym potencjałem w zakresie liczby miejsc noclegowych dysponuje Istria, na którą przypada prawie $28 \%$ wszystkich miejsc noclegowych i około $25 \%$ miejsc w pokojach hotelowych. Drugim bardzo ważnym regionem turystycznym jest Primorje-Gorski Kotar, położony na wschód i południowy wschód od Istrii. Posiada on 20-procentowy udział w liczbie miejsc noclegowych (tab. 1).

Intensywność zagospodarowania turystycznego mierzona wskaźnikiem gęstości miejsc noclegowych wynosi dla całej Chorwacji 16,7 miejsc noclegowych na $1 \mathrm{~km}^{2}$. Najwyższą gęstością charakteryzuje się Istria - 93,7 oraz Primorje-Gorski Kotar - 54,3. W pozostałych jednostkach administracyjnych wartość tego wskaźnika waha się od około 35 (Dubrownik-Neretva, Zadar, Split-Dalmatia) do 25 w żupanji Sibenik-Knin. Jedynym obszarem ze znacznie niższą gęstością bazy noclegowej jest Lika-Senj, gdzie wartość ta jest na poziomie 5,7 miejsc noclegowych na $1 \mathrm{~km}^{2}$. Region ten jest najsłabiej zagospodarowany turystycznie, co wynika zarówno z uwarunkowań przyrodniczych (bliskie sąsiedztwo obszaru górskiego), jak i kulturowych (słabo wykształcona sieć osadnicza). W pozostałych jednostkach administracyjnych gęstość bazy noclegowej jest znacznie niższa niż dla całej Chorwacji i nie jest przekracza 1,6 miejsca noclegowego na $1 \mathrm{~km}^{2}$. Jedynie Zagrzeb - miasto posiada wskaźnik na poziomie krajowym $(16,9)$. Wiąże się to z funkcją stołeczną tego miasta i rozwojem bazy hoteli miejskich.

Bardzo dużą rolę w zagospodarowaniu turystycznym Chorwacji odgrywają drugie domy, których liczba począwszy od $1960 \mathrm{r}$. systematycznie wzrastała. Na początku lat 70 . liczba drugich domów wynosiła 22,9 tys., a po 10 latach wielkość ta wynosiła 84,3 tys. (Mróz, Rettinger 1992). Proces wzrostu liczby drugich domów przebiegał dwukierunkowo. W pierwszym przypadku wiązało się to z odnawianiem i modernizacją odziedziczonych po rodzicach lub dziadkach opuszczonych zabudowań wiejskich. Zjawisko to miało charakter rozproszony. Drugi kierunek to budowa drugich domów na obszarach o szczególnych walorach wypoczynkowych i krajoznawczych, co powodowało silną koncentrację tego typu obiektów na stosunkowo niewielkich powierzchniach. Współcześnie rozmieszczenie nowopowstających drugich domów jest uwarunkowane wieloma czynnikami, przy czym jednymi z najważniejszych wydają się być odległość od stałego miejsca zamieszkania oraz walory wypoczynkowe. Do czynników uzupełniających należą koszty zakupu parceli, możliwość zakupu opuszczonych budynków mieszkalnych czy też dostępność komunikacyjna. W układzie przestrzennym rozmieszczenia drugich domów szczególna ich koncentracja uwidacznia się wokół dużych miast w promieniu do $100 \mathrm{~km}$, takich jak Zagrzeb. Kolejnym obszarem ich dużej koncentracji jest strefa nadmorska, w wąskim pasie wybrzeża. W przypadku Chorwacji drugie domy stały się integralną częścią infrastruktury turystycznej użytkowaną zarówno przez właścicieli i ich rodziny, jak i przez turystów zagranicznych. Potwierdzeniem tego faktu są liczne firmy i biura turystyczne oferujące wypoczynek w tego typu obiektach. Niestety gwałtowny rozwój drugich domów spowodował niekorzystne przekształcenia w systemie osadniczym kraju, m.in. zanikają małe górskie wsie, powstają nowe osiedla charakteryzujące się nieładem przestrzennym i nieestetyczną zabudową. Zjawisko to jest także widoczne poprzez pryzmat wykorzystania bazy noclegowej. W 2008 r. wśród różnych obiektów noclegowych największą popularnością cieszyły się kwatery prywatne, w których udzielono ponad 27\% wszystkich noclegów, dalej w kolejności znajdowały się hotele z 26,7\% oraz kempingi 23,4\%. 


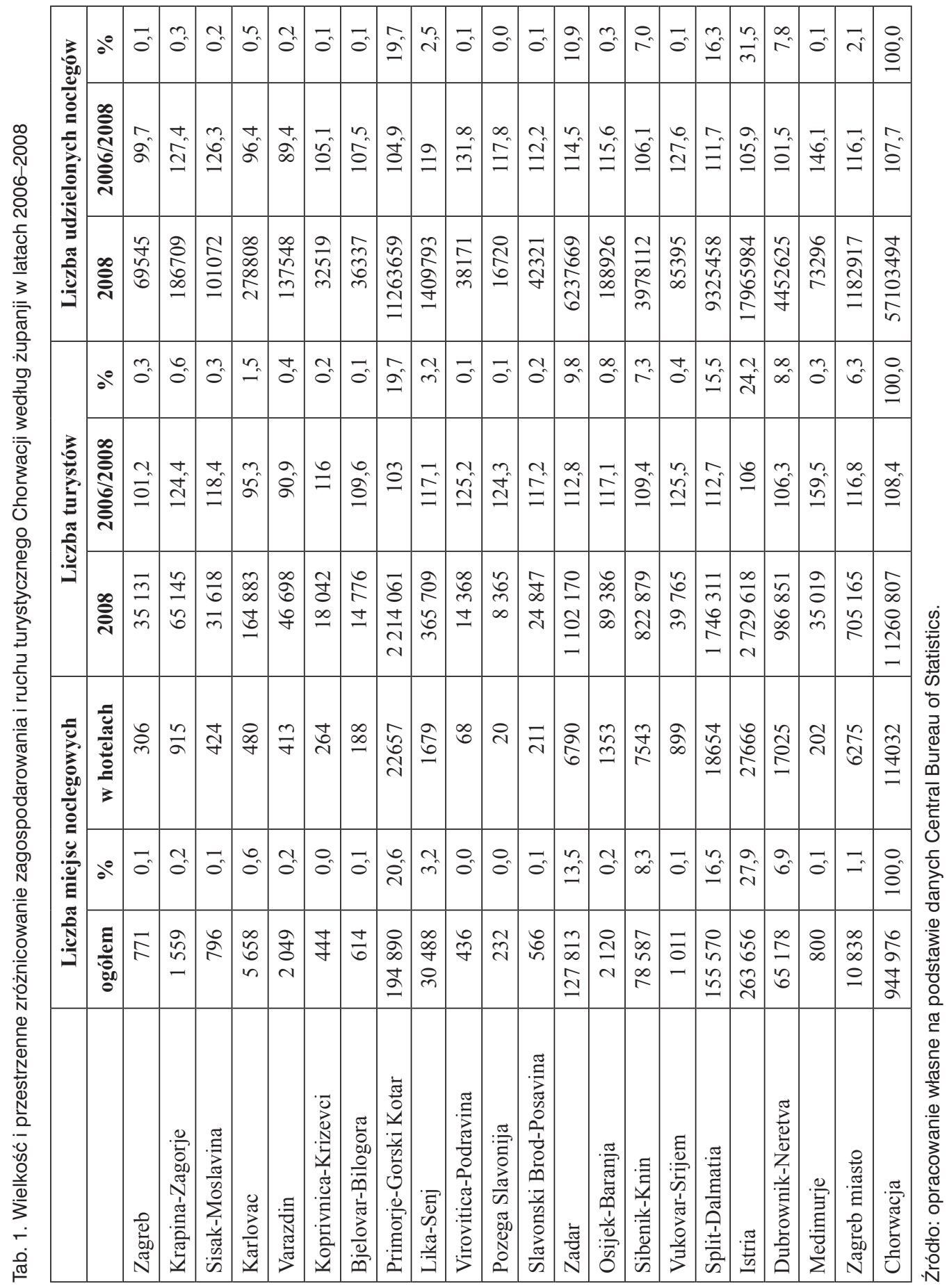


Ważnym elementem zagospodarowania turystycznego jest także baza gastronomiczna. Turyści wypoczywający w hotelach częściej korzystają z hotelowych restauracji, oferujących swoim gościom pełne wyżywienie. W przypadku Chorwacji zauważa się pewną prawidłowość - większość turystów korzysta z możliwości samodzielnego przygotowania posiłków. Wynika to chociażby z faktu, że w ofercie bazy noclegowej znaczna część apartamentów posiada kuchnię lub aneks kuchenny w pełni wyposażony w sprzęt domowy.

Chorwacja jako kraj z dobrze wykształconą funkcją turystyczną, cały czas dba o rozszerzenie i wzbogacenie oferty turystycznej. Takim działaniem jest powstawanie marin na całej długości wybrzeża. Łącznie na terenie Chorwacji funkcjonuje 49 marin z ponad 4 tys. stanowisk suchych oraz 13,5 tys. stanowisk mokrych (tab. 2). Największa liczba marin występuje na Istrii (12 marin) oraz w żupanji Sibenik-Knin (11 marin). Stosunkowo niewiele takich obiektów położonych jest w południowej części wybrzeża (Dubrownik-Neretva), tutaj mariny będą powstawać w najbliższym czasie, ponieważ jest bardzo duże zapotrzebowanie na tego typu usługi. Mariny charakteryzują się różną wielkością, jedne z największych znajdują się w okolicach Zadaru. Stałe budowanie marin jest odpowiedzią na bardzo duże zainteresowanie zagranicznych jednostek pływających możliwością stałego cumowania.

Tab. 2. Liczba marin i stanowisk w nich według żupanji - marzec 2009

\begin{tabular}{|c|c|c|c|c|c|c|c|c|c|}
\hline \multirow{3}{*}{ Żupanje } & \multicolumn{3}{|c|}{ Mariny I kategorii } & \multicolumn{3}{|c|}{ Mariny II kategorii } & \multicolumn{3}{|c|}{ Mariny III kategorii } \\
\hline & \multirow{2}{*}{$\begin{array}{l}\text { liczba } \\
\text { marin }\end{array}$} & \multicolumn{2}{|c|}{$\begin{array}{c}\text { liczba } \\
\text { stanowisk }\end{array}$} & \multirow{2}{*}{$\begin{array}{l}\text { liczba } \\
\text { marin }\end{array}$} & \multicolumn{2}{|c|}{$\begin{array}{c}\text { liczba } \\
\text { stanowisk }\end{array}$} & \multirow{2}{*}{$\begin{array}{l}\text { liczba } \\
\text { marin }\end{array}$} & \multicolumn{2}{|c|}{$\begin{array}{c}\text { liczba } \\
\text { stanowisk }\end{array}$} \\
\hline & & suche & mokre & & suche & mokre & & suche & mokre \\
\hline Istria & 3 & 400 & 1094 & 6 & 265 & 1307 & 3 & 110 & 585 \\
\hline $\begin{array}{l}\text { Primorje- } \\
\text {-Gorski Kotar }\end{array}$ & 1 & 50 & 304 & 3 & 550 & 1396 & 4 & 100 & 593 \\
\hline Zadar & 0 & 0 & 0 & 5 & 1300 & 3325 & 4 & 125 & 538 \\
\hline Sibenik-Knin & 2 & 230 & 670 & 4 & 360 & 893 & 5 & 300 & 1130 \\
\hline Split-Dalmatia & 0 & 0 & 0 & 5 & 300 & 929 & 2 & 0 & 238 \\
\hline $\begin{array}{l}\text { Dubrownik- } \\
\text {-Neretva }\end{array}$ & 0 & 0 & 0 & 2 & 200 & 535 & 0 & 0 & 0 \\
\hline Razem & 6 & 680 & 2068 & 25 & 2975 & 8385 & 18 & 635 & 3084 \\
\hline
\end{tabular}

Źródło: opracowanie własne na podstawie danych Central Bureau of Statistics.

W ostanich latach zauważa się w Chorwacji zjawisko powstawania profesjonalnych centrów nautologicznych. Ośrodki nurkowe powstają bardzo często na wyspach i są prowadzone przez chorwackie podmioty gospodarcze do tego uprawnione. W Chorwacji również posiadają swoje centra nurkowe inne kraje europejskie, w tym Polska.

W przypadku Chorwacji bardzo trudno przeanalizować faktyczne wpływy pochodzące z użytkowania infrastruktury turystycznej. Według oficjalnej statystyki, w hotelach i restauracjach zatrudnionych jest około 40 tys. pracowników, co stanowi zaledwie 2,6\% ogółu zatrudnionych. W żupanjach nadmorskich odsetek zatrudnionych w hotelach i restauracjach wzrasta do około 6\%. Są to wartości zaniżone i na pewno nie odpowiadają one faktycznemu zatrudnieniu. Podobna sytuacja występuje w generowaniu dochodów z tej gospodarczej działalności. 


\section{Wielkość i przestrzenne zróżnicowanie ruchu turystycznego}

Dzięki swoim walorom przyrodniczym i antropogenicznym Chorwacja stała się bardzo ważnym regionem turystycznym Europy, dotyczy to zarówno turystyki wypoczynkowej jak i poznawczej. Ruch turystyczny na Chorwacji charakteryzuje się również sporą koncentracją przestrzenną. Największe jego natężenie notuje się w jednostkach administracyjnych leżących na wybrzeżu, przypada na nie około $80 \%$ przyjazdów turystów do Chorwacji. Największa liczba turystów przyjeżdża na północną część wybrzeża, która jest najlepiej zagospodarowana turystycznie. Dodatkowym czynnikiem jest tu dostępność komunikacyjna, a szczególnie odległość od krajów generujących ruch turystyczny. Największa liczba turystów zagranicznych, prawie $25 \%$, zatrzymuje się na Istrii, drugie miejsce, z udziałem około $20 \%$, zajmuje Primorje-Gorski Kotar. Stosunkowo wysoki udział w przyjazdach turystycznych notuje żupanja Split-Dalmatia - 15,5\%, Zadar - 9,8\%, Dubrownik-Neretva - 8,8\% oraz Sibenik-Knin - 7,5\%. Podobnie jak w wypadku zagospodarowania turystycznego, tak i tutaj znacznie niższym udziałem charakteryzuje się żupanja Lika-Senj, której udział wynosi zaledwie 3,2\%. Na podstawie przestrzennego rozkładu ruchu turystycznego można sformułować wniosek, że obszary położone w południowej części chorwackiego wybrzeża są rzadziej odwiedzane ze względu na swoje oddalenie od krajów generujących ruch turystyczny. Ta dostępność komunikacyjna ma olbrzymie znaczenie ze względu na fakt, że olbrzymia większość turystów dociera tu własnymi samochodami. Dlatego też jednym z najważniejszych przedsięwzięć była budowa systemu autostrad łączących wybrzeże z pozostałymi częściami kraju i Europy. Te rozwiązania komunikacyjne działają bardzo dobrze, niestety w dalszym ciągu obserwuje się brak drożności komunikacyjnej na drogach lokalnych. Analizując dynamikę przyjazdów turystów do poszczególnych jednostek administracyjnych, zauważa się tendencję rosnącą. Wzrost ten był największy w żupanji Medimurje, leżącej na pograniczu chorwacko-słoweńsko-węgierskim, i wynosił on 59\%, ale udział tej jednostki administracyjnej w potencjale bazy noclegowej jest znikomy i wynosi zaledwie $0,1 \%$. Obszar ten przyjmuje $0,3 \%$ przyjazdów turystycznych (tab. 1 ).

Tab. 3. Krajowy i zagraniczny ruch turystyczny w parkach narodowych Chorwacji w $2007 \mathrm{r}$.

\begin{tabular}{|l|c|c|c|c|}
\hline \multirow{2}{*}{ Park Narodowy } & \multicolumn{4}{|c|}{ Liczba turystów } \\
\cline { 2 - 5 } & ogółem & krajowych & \multicolumn{2}{c|}{ zagranicznych } \\
\cline { 2 - 5 } & w tys. & w tys. & w tys. & \% \\
\hline \multirow{2}{*}{ Brijuni } & 178,0 & 69,3 & 108,7 & 61,0 \\
\hline Kornati & 94,6 & 34,8 & 59,8 & 63,2 \\
\hline Krka & 700,8 & 125,6 & 575,2 & 82,1 \\
\hline Mljet & 87,8 & 13,6 & 74,2 & 84,5 \\
\hline Paklenica & 110,3 & 15,5 & 94,8 & 85,9 \\
\hline Jeziora Plitwickie & 927,7 & 86,8 & 840,9 & 90,6 \\
\hline Risnjak & 24,8 & 19,8 & 5,0 & 20,2 \\
\hline Północny Velebit & 12,0 & 6,8 & 5,2 & 43,7 \\
\hline Ogółem & 2136,0 & 372,4 & 1796,7 & 84,1 \\
\hline
\end{tabular}

Źródło: opracowanie własne na podstawie danych Central Bureau of Statistics. 
Podobny rozkład przestrzenny występuje w przypadku udzielonych noclegów, gdzie po raz kolejny pierwsze miejsce zajmuje Istria, z udziałem 31,5\% liczby udzielonych noclegów (tab. 1). Dalej uplasowały się żupanie leżące na wybrzeżu.

Chorwacja jako kraj z bardzo dobrze rozwiniętym sektorem turystycznym podejmuje szereg działań mających na celu utrzymanie oraz wzrost wpływów z turystyki. Działania te obejmują m.in. badania motywów, którymi kierują się turyści wybierający ten kierunek. Już od wielu lat głównym motywem jest cel wypoczynkowy połączony z celem poznawczym. W przypadku tego drugiego najczęściej wymienianymi celami przyjazdów są: muzea i galerie (2,3 mln turystów), parki narodowe $(2,1 \mathrm{mln})$, miejsca pielgrzymkowe $(0,8 \mathrm{mln})$, stare miasta $(0,8 \mathrm{mln})$, wydarzenia kulturalne $(0,6 \mathrm{mln})$ oraz kasyna $(0,5 \mathrm{mln})$.

Obszary o szczególnych walorach przyrodniczych Chorwacji zostały objęte prawnymi formami ochrony przyrody. Utworzono tu 20 parków narodowych, z czego 6 jest wpisanych na Listę światowego dziedzictwa kulturalnego i przyrodniczego UNESCO. Na szczególną uwagę zasługują dwa parki: Jeziora Plitwickie i Paklenica.

Park Narodowy Jeziora Plitwickie powstał w 1949 r., a w 1979 r. został wpisany na Liste światowego dziedzictwa kulturalnego i przyrodniczego UNESCO. Park chroni krajobraz krasowy, z charakterystycznymi jeziorami i wodospadami. Jeziora zajmują zaledwie $1 \%$ powierzchni chronionej, jest ich około 16, łączą się one ze sobą 92 wodospadami. Największym jeziorem jest Kozjak o powierzchni 82 ha, drugim w kolejności jest Proscansko - 68 ha. Wielką atrakcją tego parku jest 80-metrowy Wielki Wodospad.

Park Narodowy Krka powstał w 1985 r. Swoim zasięgiem obejmuje on znaczny odcinek rzeki Krka od Knina po Skradin (ryc. 1), jego powierzchnia wynosi $111 \mathrm{~km}^{2}$. Został on utworzony ze względu na formy rzeźby krasowej, których najciekawsze występują na odcinku od Visovackiego Jezera po Skradin i na północ od Visovackiego Jezera. Atrakcją przyrodniczą parku jest także system wodospadów oraz dolina rzeki przypominająca swoim wyglądem kanion. Najważniejsza atrakcja antropogeniczna parku to klasztor na wyspie Visovac.

Park Narodowy Brijuni powstał w 1983 r., swym zasięgiem obejmuje 40 km² wysp i akwenów pomiędzy nimi. W jego skład wchodzi około 14 wysp, największe z nich to Veliki Brijun oraz Mali Brijun. Znaczna część wysp jest niezamieszkana przez ludzi, a jedynie przez ptaki. Wyspy te zasługują na szczególne zainteresowanie ze względu na ciekawy świat roślinny można tu zobaczyć makię oraz zagajniki dębowe i las dębowo-wawrzynowy.

Park Narodowy Paklenica powstał w 1949 r. i obejmuje swym zasięgiem najwyższe partie pasma górskiego Velebitu, najwyższej części Gór Dynarskich. Do najciekawszych miejsc parku można zaliczyć wąwozy Velika Paklenica i Mała Paklenica. Jest to obszar ciekawy nie tylko z powodów krajobrazowych, ale także jest z możliwości uprawiania turystyki wspinaczkowej i pieszej.

Park Narodowy Kornati to archipelag 147 skalistych wysp i wysepek o charakterze krasowym, leżących na przedłużeniu wyspy Dugi Otok.

Analizując funkcję ekonomiczną turystyki, należy sprawdzić, z których krajów pochodzą turyści, ponieważ to decyduje pośrednio o wielkości wpływów pochodzących z tej branży. Ustalając dalsze kierunki rozwoju turystyki, należy się skoncentrować na cechach społeczno-ekonomicznych potencjalnego turysty. Ważna jest nie tylko sytuacja finansowa, ale także demograficzna. Szczególnie interesującym problemem jest geograficzna segmentacja rynku turystycznego, czyli to, które kraje generują zagraniczny ruch turystyczny w Chorwacji.

Dzięki swoim walorom przyrodniczym i kulturowym Chorwacja stała się jednym z ważniejszych regionów turystycznych Europy W 2008 r. odwiedziło ją 11260 tys. turystów. Spośród ogółu turystów odwiedzających ten kraj najliczniejszą grupę stanowią Niemcy, 
Włosi i Słoweńcy (tab. 4). Analiza krajów pochodzenia turystów wskazuje, że Chorwacja jest jednym z najważniejszych miejsc wypoczynku turystów Europy Środkowej i Południowej. Znacznie mniejszym udziałem charakteryzują się kraje zachodniej części Europy (Hiszpania, Portugalia i Francja). Wynika to z faktu posiadania przez te kraje własnego wybrzeża Morza Śódziemnego oraz znacznie większej odległości między nimi a Chorwacją. Interesującym zagadnieniem jest bardzo duża popularność tego kraju wsród turystów włoskich, wynikająca z konkurencyjności cenowej oraz dostępności komunikacyjnej. Turyści włoscy korzystają także z usług świadczonych w marinach. Turysta europejski wybiera Chorwację ze względu na jej walory wypoczynkowe, poznawcze oraz dostępność komunikacyjną i możliwość uprawiania sportów wodnych.

Tab. 4. Liczba turystów zagranicznych oraz udzielone noclegi według głównych krajów generujących ruch turystyczny w latach 2006-2008

\begin{tabular}{|c|c|c|c|c|c|c|c|c|}
\hline \multirow{2}{*}{ Kraje } & \multicolumn{3}{|c|}{ Liczba turystów w tys. } & \multicolumn{4}{|c|}{ Udzielone noclegi w tys. } & \multirow{2}{*}{$\begin{array}{l}\text { Średnia } \\
\text { długość } \\
\text { pobytu }\end{array}$} \\
\hline & 2006 & 2008 & $2006 / 2008$ & 2006 & 2008 & $2006 / 2008$ & $\%$ & \\
\hline Niemcy & 1545 & 1548 & 100,2 & 10987 & 10983 & 99,9 & 21,7 & 7,0 \\
\hline Słowenia & 913 & 1043 & 114,2 & 5246 & 5802 & 110,6 & 11,5 & 5,6 \\
\hline Włochy & 1235 & 1168 & 94,5 & 5474 & 5069 & 92,6 & 10,0 & 4,4 \\
\hline Austria & 790 & 814 & 103,0 & 4069 & 4165 & 102,3 & 8,2 & 5,1 \\
\hline Czechy & 593 & 623 & 104,9 & 3921 & 4122 & 105,1 & 8,1 & 6,6 \\
\hline Polska & 276 & 417 & 151,2 & 1612 & 2512 & 155,8 & 5,1 & 5,7 \\
\hline Holandia & 242 & 297 & 122,9 & 1938 & 2335 & 120,5 & 4,6 & 7,7 \\
\hline Węgry & 403 & 370 & 92,0 & 2196 & 1934 & 88,0 & 3,8 & 5,2 \\
\hline Słowacja & 218 & 299 & 137,3 & 1428 & 1927 & 134,9 & 3,8 & 6,5 \\
\hline Francja & 505 & 439 & 86,9 & 1708 & 1635 & 95,8 & 3,2 & 3,5 \\
\hline Pozostałe & 1939 & 2397 & 123,6 & 8441 & 10141 & 120,1 & 20,0 & 4,3 \\
\hline
\end{tabular}

Źródło: opracowanie własne na podstawie danych Central Bureau of Statistics.

Z każdym rokiem zwiększa się liczba turystów polskich przyjeżdżających na odpoczynek do Chorwacji, w stosunku do roku 2006 liczba Polaków zwiększyła się o 51\%. Był to najwyższy zanotowany wzrost spośród pozostałych krajów europejskich, zjawisko to dotyczyło zarówno wielkości ruchu turystycznego, jak i liczby udzielonych noclegów. Przeciętny Polak przebywa na terenie Chorwacji około 6 dni.

\section{Sezonowość ruchu turystycznego}

W przypadku Chorwacji bardzo ważnym problemem jest zjawisko sezonowości ruchu turystycznego. Posiada ono przede wszystkim wymiar ekonomiczny. Największa liczba turystów przyjeżdża tam w sierpniu i lipcu. Na te dwa miesiące przypada $49 \%$ całorocznego ruchu turystycznego. Wzmożony sezon turystyczny rozpoczyna się już w maju i kończy we wrześniu, uzupełnieniem tego sezonu są jeszcze kwiecień i październik. Najmniejsza liczba turystów, zaledwie 2,3\% całorocznego ruchu turystycznego, przypada na styczeń i luty. Bardzo interesująco przedstawia się sezonowość ruchu turystycznego w zależności od formy wypoczynku: 
zorganizowanej lub indywidualnej. W wypadku turystów, którzy w sposób zorganizowany wypoczywają w Chorwacji, można zauważyć, że w żadnym z miesięcy udział ich w ruchu turystycznym nie przekracza 49\%. A największe natężenie ruchu turystycznego notuje się w miesiącach bezpośrednio poprzedzających wzmożony sezon turystyczny (lipiec, sierpień) i tuż po nim (tab. 5). Turyści indywidualni najliczniej przybywają w lipcu i sierpniu, w tych miesiącach ich udział stanowi około $75 \%$ całości ruchu turystycznego. W miesiącach zimowych, od listopada do lutego, notuje się obniżenie wielkości ruchu turystycznego z równoczesną przewagą turystyki indywidualnej.

Warunki przyrodnicze, które warunkują długość sezonu turystycznego, przekładają się także na długość pobytu. W 2007 r. średnia długość pobytu wynosiła 3,6 dnia, oczywiście w lipcu i sierpniu wzrasta ona do wartości około 6 dni, co jest związane z wypoczynkowym charakterem turystyki.

Tab. 5. Sezonowość ruchu turystycznego

\begin{tabular}{|c|c|c|c|c|}
\hline \multirow{2}{*}{ Miesiące } & \multicolumn{3}{|c|}{ Przyjazdy turystów w tys. } & \multirow{2}{*}{$\begin{array}{c}\text { Średnia długość } \\
\text { pobytu }\end{array}$} \\
\cline { 2 - 4 } & Ogólem & $\begin{array}{c}\text { Zorganizowany } \\
\text { udzial w \% }\end{array}$ & $\begin{array}{c}\text { Indywidualny } \\
\text { udzial w \% }\end{array}$ & \\
\hline Styczeń & 121,6 & 22,7 & 77,3 & 2,5 \\
\hline Luty & 140,7 & 29,8 & 70,2 & 2,4 \\
\hline Marzec & 227,3 & 40,1 & 59,9 & 2,4 \\
\hline Kwiecień & 601,5 & 46,2 & 53,8 & 2,8 \\
\hline Maj & 892,3 & 47,6 & 52,4 & 3,4 \\
\hline Czerwiec & 1559,1 & 40,9 & 59,1 & 4,6 \\
\hline Lipiec & 2646,1 & 26,8 & 73,2 & 6,2 \\
\hline Sierpień & 2819,2 & 25,1 & 74,9 & 6,4 \\
\hline Wrzesień & 1283,9 & 43,1 & 56,9 & 4,8 \\
\hline Październik & 490,9 & 48,7 & 51,3 & 3,0 \\
\hline Listopad & 208,0 & 33,2 & 66,8 & 2,4 \\
\hline Grudzień & 171,8 & 32,3 & 67,7 & 2,3 \\
\hline
\end{tabular}

Źródło: opracowanie własne na podstawie danych Central Bureau of Statistics.

Zjawisko sezonowości ruchu turystycznego przekłada się w sposób zasadniczy na wpływy osiagane przez ten sektor gospodarki narodowej. Według informacji publikowanych przez Chorwacki Urząd Statystyczny w 2008 r., udział turystyki w tworzeniu PKB wyniósł 15,7\%. Analizując udział turystyki w tworzeniu PKB w poszczególnych kwartałach roku, zauważa się wahania od 2,8\% w pierwszym kwartale do 35,5\% w kwartale obejmującym lipiec, sierpień i wrzesień. Większa aktywność organizatorów turystyki w miesiącach poza zasadniczym sezonem turystycznym wynika z faktu konieczności ograniczenia negatywnych ekonomicznych skutków sezonowości turystycznej. W tym okresie organizowane są tańsze wyjazdy dla emerytów, a także konferencje i kongresy, które mają na celu poprawić sytuację w zakresie wpływów finansowych pochodzących z tego rodzaju działalności gospodarczej. 


\section{Literatura}

1. Butler R., 2005., Problemy miejsc recepcji turystycznej ze zrównoważonym rozwojem [w:] Turystyka w badaniach naukowych, red. R. Winiarski, W. Alejziak, Kraków-Rzeszów.

2. Gaworecki W., 2007, Turystyka, Państwowe Wydawnictwo Ekonomiczne, Warszawa.

3. Jędrzejczyk I., 1999, Polityka Unii Europejskiej wobec regionów turystycznych [w:] Europejskie uwarunkowania przemian układów regionalnych, pod red. Z. Zioło, „Zeszyty Naukowe”, nr 2, Wyższa Szkoła Informatyki i Zarządzania w Rzeszowie.

4. Mróz G., Rettinger R., 1992, Baza turystyczno-wypoczynkowa Jugosławii i jej wpływ na zróżnicowanie społeczno-ekonomiczne i osadnicze kraju, „Folia Turistica”, nr 3, Akademia Wychowania Fizycznego, Kraków.

5. Wiluś R., Włodarczyk B., 1996, Współczesne problemy rozwoju turystyki dalmatyńskiego wybrzeża Chorwacji, „Turyzm”, t. 6, z. 2, Wydawnictwo Uniwersytetu Łódzkiego, Łódź.

\section{Tourism as an Incentive to Economic Growth in Croatia}

Tourism is an important means of income transfer from wealthy countries to less affluent ones, which diminishes differences in development levels between the two regions. By satisfying the various needs and boosting socio-economic development, tourism directly and indirectly influences the levels of GDP. In Croatia, tourism contributes a significant $15.7 \%$ of the country's GDP. Croatia has rather a wide range of accommodation with a total capacity of approx. 950.000 beds in hotels $(12 \%)$, holiday homes $(6 \%)$, campsites $(23 \%)$ and private accommodation (44\%). The latter, typical for Croatia, is linked to the common practice of owning weekend houses. The largest numbers of international tourists stay in Istria (nearly $25 \%$ ) and Primorje-Gorski Kotar (20\%). Relatively high percentages of visitors from abroad are also present in the counties of Split-Dalmatia (15.5\%), Zadar (9.8\%), Dubrovnik-Neretva $(8.8 \%)$ and Sibenik-Knin $(7.5 \%)$. Thanks to its natural and cultural attractions, Croatia has become an important tourist region in Europe. In 2008 it was visited by $11.26 \mathrm{mln}$ tourists, mostly from Germany, Italy and Slovenia. 